\title{
Influence of Putrescine on Enzymes of Ammonium Assimilation in Maize Seedling
}

\author{
Vineeta Awasthi $^{1}$, Indreshu Kumar Gautam ${ }^{1}$, Rakesh Singh Sengar ${ }^{2}$, Sanjay Kumar Garg ${ }^{{ }^{*}}$ \\ ${ }^{1}$ Department of Plant Science, M.J.P. Rohilkhand University, Bareilly, India; ${ }^{2}$ Sardar Vallabh Bhai Patel University of Agriculture \\ and Technology, Meerut, India. \\ Email: *gargskplantscience@gmail.com
}

Received October $20^{\text {th }}, 2012$; revised November $22^{\text {nd }}, 2012$; accepted November $20^{\text {th }}, 2012$

\begin{abstract}
The effect of different concentrations of putrescine on biochemical changes in root and shoot of six days old maize seedlings in terms of enzymes of ammonium assimilation were examined. The results revealed that glutamate dehydrogenase (GDH) activity was enhanced at lower concentration of putrescine but at higher concentration, the activity of this enzyme was declined. Glutamine synthetase (GS) activity decreased with increase in concentration of putrescine and it was highest at $1000 \mu \mathrm{m}$ concentration. Howe ver, glutamate synthase (GOGAT) activity increased with increase in concentration of putrescine upto $100 \mu \mathrm{m}$ in root and upto $50 \mu \mathrm{m}$ in shoot and further increase in concentration resulted in decline of enzymatic activity. Protein and total nitrogen content increased upto $10 \mu \mathrm{m}$ concentration of putrescine and it decreased further with increase in concentration both in root and shoot of maize seedling.
\end{abstract}

Keywords: Glutamate Dehydrogenase; Glutamine Synthetase; Glutamate Synthase; Maize Seedlings; Putrescine; Zea mays

\section{Introduction}

In all tissues of higher plants nitrogen is assimilated into organic compounds by the glutamate synthase cycle, the enzymes glutamate dehydrogenase (GDH, EC 1.4.1.2-4), glutamine synthetase (GS) and glutamate synthase (GO GAT) plays crucial role to assimilate ammonium ion via glutamate dehydrogenase (GDH) or glutamine synthetase (GS:E.C.6.3.1.2) and glutamate synthase (GOGAT:E.C. 1.4.7.1) (GS-GOGAT) route. Evidences from recent works suggest that GS-GOGAT pathway is the major route for ammonia assimilation to produce glutamate in the plants under normal growth conditions [1-5].

The naturally occurring polyamines-putrescine (PUT), spermidine (SPD) and spermine (SPM) are important polycationic molecules that are ubiquitously present across the living world. These nitrogenous aliphatic compounds are known to influence a variety of biological processes. The most important characteristic of polyamines being the polycationic nature, they are implicated in electrostatic interactions with the negatively charged molecules in the cell. Since last decade, understanding of the involvement of polyamines in cellular and developmental processes across the living systems has been increased [6-8]. However, very little work has been done

"Corresponding author. on effect of this growth regulator on enzymes of ammonium assimilation. Keeping above in view, the present investigation was carried out to study the effect of putrescine on the enzymes of ammonium assimilation viz. glutamate dehydrogenase (GDH), glutamine synthetase (GS) and glutamate synthase (GOGAT). The activities of the enzymes of nitrogen metabolism decrease during senescence. In general, the activity of nitrate reductase (NR) is the first to be lost. The activities of glutamine synthetase (GS), glutamate synthase (GOGAT) and glutamate dehydrogense (GDH) stay on for longer period [9].

Glutamate synthetase (GS) is the enzymes of glutamate synthesis in the senescent leaves $[10,11]$. However, the GS activity goes down in the same way as its happens with RUBISCO [12]. Glutamate synthetase exists in at least two isoforms:GS1 is a cytosolic enzymes while GS2 is in the chloroplast [11], The decrease in GS activiity during senescence can be due to the decrease of the GS2 isoform. In the same way as the other chloroplastic proteins GS2 is hydrolyzed during this period. In isolated chloroplast, it was observed that GS2 hydrolyze and degradation goes faster than Rubisco's and the other carbon assimilation enzymes [13], On the other hand cytosolic GS1 is kept constant or may even increase its activity during senescence [14]. As GS1 changes glutamate into 
glutamine, it increases the $\mathrm{N}$ transport efficiency, since glutamate has a $5 \mathrm{C}: 2 \mathrm{~N}$ ratio. Another indication that the cytosolic GS1 is related to the remobilization of $\mathrm{N}$ is the increase of the expression of the GS1 genes during senescence. Also, post translational phosphorylation of GS1 protects the enzymes against degradation. Interaction with 14-3-3 proteins can also increase GS1 activity [15].

Although during the reproductive period total GS activity (GS1 + GS2) decreases, GS1 remains active in the production of glutamine from glutamate and ammonium. In this way, cytosolic GS is closely related to the synthesis of the transport of substances, after the degradation of proteins. Besides GS1 there also have been observed increases in the activities of NADH-GOGAT and GDH, which suggest the participation of these enzymes in the remobilization of nitrogen [16].

GDH is one of the few enzymes that can remove nitrogen directly from amino acids, resulting in the production of keto acids and ammonium, both of which can be remobilized to be used in respiration and synthesis [17, 18]. working with a maize land race (sol da manha), breed through a participatory process involving small farmers, have shown that this variety was much more efficient than the commercial hybrids when growing in soils depleted of nutrients specially nitrogen. Through studies of the enzymes of nitrogen assimilation, this ability was related by the authors to a higher capacity of "sol da manha" to take up $\mathrm{NH}_{4}^{+}-\mathrm{N}$ from the soil. Data from [18] indicates that under $\mathrm{NH}_{4}^{+}$-nutrient, GS activity is closely related to the dry matter accumulation and the reduction of level in the tissues. Studying the nitrogen use efficiency in endogamic families of maize (sol da manha and cateto) in nutrient solutions using two nitrogen levels (10 and $100 \mathrm{mg} \mathrm{N} / \mathrm{L}$ ) [18], have found higher activity of GS for plants under $\mathrm{NH}_{4}^{+}$, and higher $\mathrm{NR}$ activity for plants under $\mathrm{NO}_{3}^{-}$. These authors related the higher nitrogen use efficiency of these plants to its superior capacity to take up nitrogen under a range of environmental conditions.

\section{Materials and Methods}

Seeds of Zea mays L. cv. Ganga Safed-2, procured from National Seed Corporation, New Delhi were surface sterilized with $0.1 \% \mathrm{HgCl}_{2}$ for $5 \mathrm{~min}$. and then washed thoroughly with distilled water. The sterilized seed were placed in $15 \mathrm{~cm}$ petriplate lined with Whatman No. 1 filter paper and allowed to germinate at $25^{\circ} \mathrm{C} \pm 2^{\circ} \mathrm{C}$ under $14 \mathrm{hr}$. photoperiod of approximately $70 \mathrm{Wm}^{-2}$ radiant flux density. There were three replications with 30 seeds for each treatment. The first set was supplied with Hoagland's nutrient solutions [19]. to serve as control while set 2, 3, $4 \& 5$ were supplied with 10, 50, 100 and $1000 \mu \mathrm{m}$ aqueous solutions of putrescine, respectively.
All the petri-plates were kept wet by supplying respecttive solutions daily. Emergence of radicle was taken as a criterion for the out set of seed germination in each treatment. On 6th day of sowing, roots and shoots of maize seedlings were used separately for nitrogen, protein and enzyme analysis.

\subsection{Determination of Enzyme Activity}

\subsubsection{Glutamate Dehydrogenase Activity}

Glutamate dehydrogenase (GDH) from the fresh sample was extracted in a mortar, containing a medium of $0.5 \mathrm{M}$ sodium phosphate buffer ( $\mathrm{pH}$ 7.4), $0.4 \mathrm{M}$ sucrose and 2 mM EDTA. The clear supernatant was used as enzyme preparation to assess the enzyme activity [20].

\subsubsection{Glutamine Synthetase Activity}

Enzyme extract were prepared in cold in a mortar containing $50 \mathrm{mM}$ Tris- $\mathrm{HCl}(\mathrm{pH} 7.8), 15 \%$ (v/v) glycerol, 14 $\mathrm{mM}$ 2-mercaptoethanol, $1.0 \mathrm{mM}$ EDTA and $0.1 \%(\mathrm{w} / \mathrm{v})$ Triton X-100. The supernatant was used for determination of enzyme activity [21].

\subsubsection{Glutamate Synthase Activity}

Enzyme was extracted in a medium containing $0.2 \mathrm{M}$ sodium phosphate buffer ( $\mathrm{pH} 7.5$ ), $2 \mathrm{mM}$ EDTA, $50 \mathrm{mM}$ $\mathrm{KCl}, 0.1 \%$ mercaptoethanol and $0.5 \%$ Triton $\mathrm{X}-100$ in a ratio of $1: 4(\mathrm{w} / \mathrm{v})$. The clear supernatant was used as enzyme preparation. Glutamate synthase activity (NADHspecific) was determined using oxidation of NADH [22].

\subsubsection{Determination of Total Nitrogen and Protein}

The total nitrogen was determined after digestion with concentrated sulphuric acid by a modified micro-Kjeldahl method [23]. Protein content in shoot and root of maize seedlings was also estimated [24].

\subsubsection{Statistical Analysis}

The data presented throughout are the average value \pm standard errors of at least 3 independent series, each with two replicate determinates and was calculate $\mathrm{SD}$ and $\pm \mathrm{SE}$.

\section{Results and Discussion}

Concentration of putrescine and the tissue used to show the effect of putrescine on enzymes of ammonium assimilation in root and shoot of maize seedling. Total and specific glutamate dehydrogenase (GDH) activity increased upto $10 \mu \mathrm{M}$ concentration of putrescine i.e. $40 \%$ and $36 \%$, respectively in root and thereafter it decreased gradually upto $1000 \mu \mathrm{M}$, whereas in shoot it was maximum at $50 \mu \mathrm{M}$ concentration i.e. $11 \%$ and $8 \%$ and further increase resulted in decreased activity (Tables 1 and 2).

Total and specific glutamine synthetase (GS) activity 
decreased i.e. $29 \%$ and $10 \%$ at $100 \mu \mathrm{M}$ concentration in root, whereas, in shoot it decreased to $42 \%$ and $34 \%$, respectively. At higher concentration $(1000 \mu \mathrm{M})$, it was found to be increased both in root and shoot of maize seedlings (Tables 1 and 2).

Total and specific glutamate synthase (GOGAT) activity was found to be increased $54 \%$ and $26 \%$ in root at $100 \mu \mathrm{M}$ concentration and thereafter it decreased whereas in shoot these two activities increased by $57 \%$ and $30 \%$ at $50 \mu \mathrm{M}$ concentration and further increase in con- centration resulted in decline in total as well as specific GOGAT activities (Tables 1 and 2). Protein content was found to be increased $112 \%$ and $94 \%$ in root and shoot, respectively, at $10 \mu \mathrm{M}$ concentration and further increase in concentration resulted in decline in protein content (Figure 1). An increase in total nitrogen content i.e. $82 \%$ and $91 \%$ at $10 \mu \mathrm{M}$ concentration was observed both in root and shoot of maize seedling, respectively and further increase in concentration resulted in decrease in nitrogen content (Figure 2).

Table 1. Effect of Putrescine on total enzyme activity of ammonium assimilation in maize seedling.

\begin{tabular}{|c|c|c|c|c|c|c|}
\hline \multirow[t]{2}{*}{ Conc. $(\mu \mathrm{M})$} & \multicolumn{2}{|c|}{$\begin{array}{c}\text { GDH activity (NADH } \\
\text { oxidized } \mathrm{min}^{-1} \text { ) } \mathrm{g}^{-1} \text { fresh wt. }\end{array}$} & \multicolumn{2}{|c|}{$\begin{array}{c}\text { GS activity (GHA } \min ^{-1} \text { ) } \\
\mathrm{g}^{-1} \text { fresh wt. }\end{array}$} & \multicolumn{2}{|c|}{$\begin{array}{l}\text { GOGAT activity (NADH } \\
\text { oxidized } \text { min }^{-1} \text { ) } \mathrm{g}^{-1} \text { fresh wt. }\end{array}$} \\
\hline & Root & Shoot & Root & Shoot & Root & Shoot \\
\hline 0.0 & $794.84 \pm 1.93(100)$ & $460.09 \pm 1.92(100)$ & $23.96 \pm 0.08(100)$ & $32.99 \pm 0.08(100)$ & $1898.99 \pm 2.88(100)$ & $1456.73 \pm 4.76(100)$ \\
\hline 10 & $1053.41 \pm 3.18(140)$ & $468.83 \pm 0.73(109)$ & $18.90 \pm 0.21(79)$ & $21.75 \pm 0.08(66)$ & $2154.52 \pm 4.76(113)$ & $1906.63 \pm 3.78(131)$ \\
\hline 50 & $565.65 \pm 1.26(75)$ & $511.78 \pm 2.62(111)$ & $17.92 \pm 0.09(75)$ & $21.21 \pm 0.05(64)$ & $2501.77 \pm 2.89(132)$ & $2281.19 \pm 2.89(157)$ \\
\hline 100 & $516.87 \pm 1.92(68)$ & $297.75 \pm 1.93(64)$ & $16.92 \pm 0.09(71)$ & $19.16 \pm 0.08(58)$ & $2928.74 \pm 3.78(154)$ & $1767.95 \pm 2.88(121)$ \\
\hline 1000 & $337.79 \pm 1.93(45)$ & $250.43 \pm 1.93(54)$ & $19.84 \pm 0.08(83)$ & $20.51 \pm 0.09(62)$ & $1384.65 \pm 4.75(73)$ & $1379.19 \pm 5.00(95)$ \\
\hline
\end{tabular}

Data $\pm \mathrm{SE}$, The values relative to control are given in parenthesis.

Table 2. Effect of Putrescine on specific enzyme activity of ammonium assimilation in maize seedling.

\begin{tabular}{ccccccc}
\hline Conc. $(\mu \mathrm{M})$ & \multicolumn{2}{c}{$\begin{array}{c}\text { GDH activity }(\mathrm{NADH} \\
\left.\text { oxidized } \mathrm{min}^{-1}\right) \mathrm{mg}^{-1} \text { protein }\end{array}$} & \multicolumn{2}{c}{ GS activity $\left(\mathrm{GHA} \mathrm{min}^{-1}\right) \mathrm{mg}^{-1}$ protein } & \multicolumn{2}{c}{$\begin{array}{c}\text { GOGAT activity (NADH } \\
\left.\text { oxidized } \mathrm{min}^{-1}\right) \mathrm{mg}^{-1} \mathrm{protein}^{2}\end{array}$} \\
\hline & Root & Shoot & Root & Shoot & Root & Shoot \\
\hline 0.0 & $14.21 \pm 0.01(100)$ & $9.72 \pm 0.02(100)$ & $0.472 \pm 0.01(100)$ & $0.601 \pm 0.02(100)$ & $51.5 \pm 0.26(100)$ & $31.65 \pm 0.24(100)$ \\
10 & $19.38 \pm 0.14(136)$ & $9.81 \pm 0.03(101)$ & $0.468 \pm 0.02(99)$ & $0.443 \pm 0.03(74)$ & $56.98 \pm 0.22(111)$ & $40.51 \pm 0.25(128)$ \\
50 & $10.11 \pm 0.03(71)$ & $10.54 \pm 0.07(108)$ & $0.447 \pm 0.02(95)$ & $0.442 \pm 0.01(73)$ & $58.94 \pm 0.46(114)$ & $41.23 \pm 0.12(130)$ \\
100 & $8.90 \pm 0.06(62)$ & $6.00 \pm 0.04(61)$ & $0.425 \pm 0.01(90)$ & $0.398 \pm 0.02(66)$ & $64.79 \pm 0.25(126)$ & $34.31 \pm 0.32(108)$ \\
1000 & $6.89 \pm 0.06(48)$ & $5.47 \pm 0.05(56)$ & $0.545 \pm 0.03(115)$ & $0.454 \pm 0.03(75)$ & $41.30 \pm 0.15(80)$ & $23.12 \pm 0.33(73)$ \\
\hline
\end{tabular}

Data \pm SE, The values relative to control are given in parenthesis.

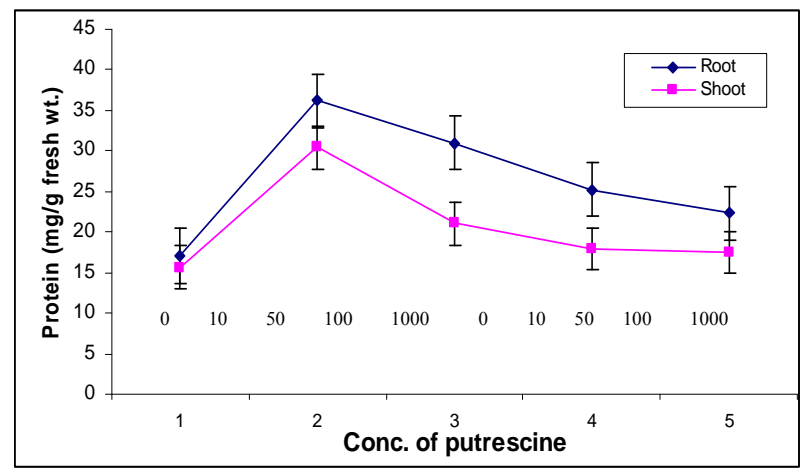

Figure 1. Effect of putrescine $(\mu \mathrm{M})$ on protein content in root and shoot of maize seedling $1=0.0 \mu \mathrm{M}, 2=10 \mu \mathrm{M}, 3=$ $50 \mu \mathrm{M}, 4$ = $100 \mu \mathrm{M}, 5=1000 \mu \mathrm{M}$.

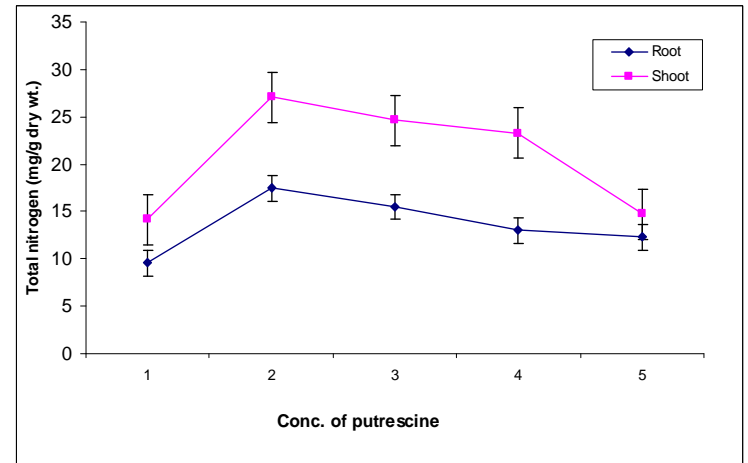

Figure 2. Effect of putrescine $(\mu \mathrm{M})$ on total nitrogen content in root and shoot of maize seedling $1=0.0 \mu \mathrm{M}, 2=10 \mu \mathrm{M}, 3$ $=50 \mu \mathrm{M}, 4=100 \mu \mathrm{M}, 5=1000 \mu \mathrm{M}$. 
Polyamines play a major role in cellular and developmental processes $[25,26]$. It is well established that growth regulator, polyamines, affect various aspect of nucleic acid, protein synthesis, membrane organization and function $[7,27,28]$. Exogenous supply of polyamines affects a variety of plant processes [29]. Increased GDH activity and declined GS activity were also reported in leaf protoplast from rape cv. Bronowski [30]. The increase of total nitrogen in leaves of Leucaena seedlings by the treatment of $100 \mu \mathrm{M}$ spermidine (family member of putrescine) was also reported [31]. The maximum increase in total nitrogen using putrescine was also obtained in Populus deltoids [32].

\section{REFERENCES}

[1] P. J. Lea, S. A. Robinson and G. R. Stewart, "The Enzymology and Metabolism of Glutamine, Glutamate and Asparagines," In: B. J. Miflin and P. J. Lea, Eds, The Biochemistry of Plants: A Comprehensive Treatise, Intermediary Nitrogen Metabolism, Academic Press, New York, 1990, pp. 121-159.

doi:10.1016/B978-0-08-092616-2.50010-3

[2] R. S. Senger, R. C. Pant, R. P. Singh and H. S. Srivastava, "Role and Regulation of Glutamine Synthesise and Glutamate Syntheses in Higher Plants," Plant Physiology and Biochemistry, Vol. 22. No. 2, 1983, pp. 89-100.

[3] H. S. Srivastava, N. Shankar and T. Yamaya, "Role and Regulation of Glutamate Synthases in Higher Plants," Physiology and Molecular Biology of Plants, Vol. 8 No. 1, 2002, pp. 39-60.

[4] G. Glevarec, S. Bouton,, E. Jaspard, M. T. Riou, J. B. Cliquet, A. Suzuki and A. M. Limami, "Respective Roles of the Glutamine Synthetase/Glutamate Synthase Cycle and Glutamate Dehydrogenase in Ammonium and Amino Acid Metabolism during Germination and Post-Germination Growth in the Model Legume Medicago truncatula," Planta, Vol. 219. No. 2, 2004, pp. 286-297.

[5] C. M. Daubresse, M. R. Cren, K. Pagean, M. Lelandais, O. Grandijean, J. Kronenberger, M. H Valadie, M. Feraud, T. Jouglet and A. Suzuki, "Glutamate Synthetase-Glutamate Synthase Pathway and Glutamate Dehydrogenase Play Distinct Roles in the Sink-Source Nitrogen Cycle in Tobacco," Plant Physiology, Vol. 140, No. 2, 2006, pp. 444- 456.

[6] S. Pandey, T. A. Ranada, P. K. Nagar and N. Kumar, "Role of Polyamines and Ethylene as Modulators of Plant Senescence," Journal of Bioscience, Vol. 25, No. 3, 2000, pp. 291-299.

[7] I. M. Talaat, M. A. Bekheta and M. H. Mahgoubi, "Physiological Response of Periwinkle Plants (Catharanthus roseus L.) to Tryptophan and Putrescine," International Journal of Agriculture and Biology, Vol. 7, No. 2, 2005, pp. 210-213.

[8] S. V. Kumar, M. L. Sharma and M. V. Rajam, "Polyamine Biosynthetic Pathways as a Novel Target for Potential Applications in Plant Biotechnology," Physiology and Molecular Biology of Plants, Vol. 12, No. 1, 2006, pp. 13-28.

[9] R. Storey and L. Beevers, "Enzymology of Glutamine Metabolism Related to Senescence and Seed Development in Pea (Pisum sativum L)," Plant Physiology, Vol. 61, No. 4, 1978, pp. $494-500$.

[10] B. J. Miflin and P. J. Lea, "Amino Acid Metabolism," Annual Review of Plant Physiology, Vol. 28, 1977, pp. 299-329.

[11] A. Oaks and B.Hirel, "Nitrogen Metabolism in Roots," Annual Review of Plant Physiology, Vol. 33, No. 1, 1985, pp. 345-365.

[12] K. Kamachi, T. Yamaya, T. Hayakawa, T. Mae and K. Ojima, "Vascular Bundlespecific Localization of Cytosolic Glutamine-Synthetase in Rice Leaves," Plant Physiology, Vol. 99, No. 4, 1972, pp. 1481-1486. doi:10.1104/pp.99.4.1481

[13] N. M. Crawford, "Nitrate: Nutrient and Signal for Plant Growth," Plant Cell, Vol. 7, No. 7, 1995, pp. 858-868.

[14] A. Makino, T. Mae and K. Ohira, "Photosynthesis and Ribulose 1,5-Bisphosphate Carboxylase in Rice LeavesChange in Photosynthesis and Enzymes Involved in Carbon Assimilation from Leaf Development through Senescene," Plant Physiology, Vol. 73, 1983, pp. 1002-1007.

[15] J. Finnemann and J. K Schioerring, "Post Translational Regulation of Cytosolic Glutamine Synthetase by Reversible Phosphorylation and 14-3-3 Protein Interaction," Plant Journal, Vol. 24, No. 2, 2000, pp. 171-181. doi:10.1046/j.1365-313x.2000.00863.x

[16] B. Hirel, P. Bertin, I. Quillere, W. Bourdoncle, C. Attagnant, C. Dellay, A. Gouy, S. Cadiou, C. Retailliau, M. Falqu and A. Gallais, "Towards a Better Understanding of the Genetic and Physiological Basis for Nitrogen Use Efficiency in Maize," Plant Physiology, Vol. 125, No. 3, 2001, pp. 1258-1270.

[17] B. J. Mifflin and D. Z Habish, "The Role of Glutamine Synthetase and Glutamate Dehydrogenase in Nitrogen Assimilation and Possibilities for Improvement in the Nitrogen Utilization of Crops," Journal of Experimental Botany, Vol. 53, No. 370, 2002, pp. 979-987.

[18] A. T. Machado and M. S. Fernandes, "Participatory Maize Breeding for Low Nitrogen Tolerance," Euphytica, Vol. 122, No. 3, 2001, pp. 567-573.

[19] J. Arditti and A. Dunn, "Experimental Plant Physiology," Rinehart H, Winston, New York, 1969, p. 265.

[20] R. P. Singh and H. S. Srivastava, "Regulation of Glutamate Dehydrogenase Activity by Amino Acids in Maize Seedlings," Plant Physiology, Vol. 57, No. 4, 1983, pp. 549-554.

[21] C. Lillo, "Diurnal Variations of Nitrite Reductase, Glutamine Synthetase, Glutamate Synthase, Alanine Amino Transferase and Aspartate Amino Transferase in Barley Leaves," Plant Physiology, Vol. 61, No. 2, 1984, pp. 214218.

[22] R. P. Singh and H. S. Srivastava, "Increase in Glutamate Synthase (NADH) Activity in Maize Seedlings in Response to Nitrite and Ammonium Nitrogen," Plant Physiology, Vol. 66, No. 2, 1986, pp. 413-416.

[23] C. A. Lang, "Simple Micro Determination of Kjeldahl 
Nitrogen in Biological Materials," Analytical Chemistry, Vol. 30, No. 10, pp. 1692-1694.

[24] O. H. Lowry, N. J. Rosebrough, A. J. Farr and R. J. Randal, "Protein Measurement with Folin-Phenol Reagent," Journal of Biological Chemistry, Vol. 193, No. 1, 1951, pp. 265- 275.

[25] E. Walden, A. Cordeir and A. R. Tiburcio, "Polyamines: Small Molecules Triggering Pathways in Plant Growth and Development," Plant Physiology, Vol. 113, No. 4, 1997, pp. 1009- 1013.

[26] M. V. Rajam, F. Shoeb and J. S. V. Yada, "Polyamines as Modulators of Plant Regeneration in Tissue Cultures," In: P. S. Srivastava, Ed., Plant Tissue Culture and Molecular Biology: Applications and Prospects, Narosa Publishing House, New Delhi, pp. 620-641.

[27] R. D. Slocum, R. Kaur-Shawney and A. W. Galston, "The Physiology and Biochemistry of Polyamines in Plants," Archives of Biochemistry and Biophysics, Vol. 235, No. 2, 1984, pp. 283-303.
[28] K. Kashiwag, Y. Yamaguchi, Y. Sakai, H. Kobayashi and K. Igarashi, "Identification of the Polyamine-Induced Protein as a Periplasmic Oligopeptide Binding Protein," Journal of Biological Chemistry, Vol. 265, No. 15, 1990, pp. 8387-8391.

[29] T. A. Smith, "Polyamines," Annual Review of Plant Physiology, Vol. 36, 1985, pp. 117-143.

[30] M. Watanabe, H. Kawasaki, Y. Itho and Y. Watanabe, "Senescence Development of Brassica napus Leaf Protoplast during Isolation and Subsequent Culture," Journal of Plant Physiology, Vol. 152, No. 4, 1998, pp. 487-493.

[31] S. Pandey and H. S. Srivastava, "Stimulation of Growth and Nitrate Assimilation in Leucaena leucocephala Seedlings in Response to Spermidine Supply," Biologica Plantarum, Vol. 37, No. 1, 1994, pp. 153-157.

[32] A. Prakash and H. S. Srivastava, "Growth and Nitrogen Assimilation in Populus Inent in Pea (Pisum sativum L.)," Plant Physiology, Vol. 61, 2000, pp. 494-500. 